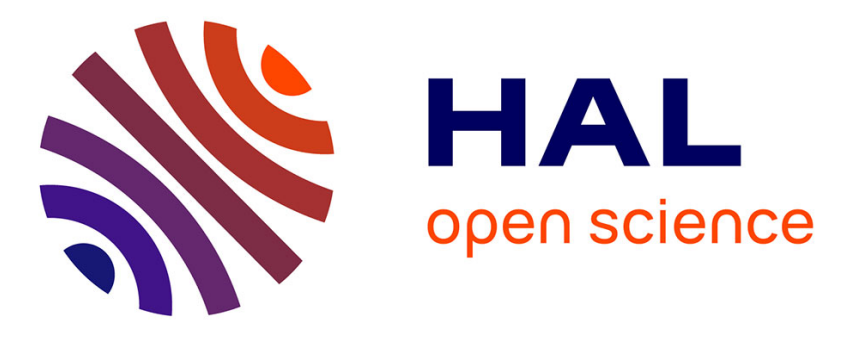

\title{
Pulmonary exposure to metallic nanomaterials during pregnancy irreversibly impairs lung development of the offspring
}

Emmanuel Paul, Marie-Laure Franco-Montoya, Erwan Paineau, Bernard

Angeletti, Shamila Vibhushan, Audrey Ridoux, Arnaud Tiendrebeogo, Murielle Salome, Bernhard Hesse, Delphine D. Vantelon, et al.

\section{To cite this version:}

Emmanuel Paul, Marie-Laure Franco-Montoya, Erwan Paineau, Bernard Angeletti, Shamila Vibhushan, et al.. Pulmonary exposure to metallic nanomaterials during pregnancy irreversibly impairs lung development of the offspring. Nanotoxicology, 2017, 11 (4), pp.484-495. 10.1080/17435390.2017.1311381 . inserm-03109063

\section{HAL Id: inserm-03109063 https://www.hal.inserm.fr/inserm-03109063}

Submitted on 13 Jan 2021

HAL is a multi-disciplinary open access archive for the deposit and dissemination of scientific research documents, whether they are published or not. The documents may come from teaching and research institutions in France or abroad, or from public or private research centers.
L'archive ouverte pluridisciplinaire HAL, est destinée au dépôt et à la diffusion de documents scientifiques de niveau recherche, publiés ou non, émanant des établissements d'enseignement et de recherche français ou étrangers, des laboratoires publics ou privés. 


\section{Pulmonary exposure to metallic nanomaterials during pregnancy irreversibly impairs lung development of the offspring}

Emmanuel Paul ${ }^{1,2}$, Marie-Laure Franco-Montoya ${ }^{1,2}$, Erwan Paineau ${ }^{3}$, Bernard Angeletti $^{4}$, Shamila Vibhushan ${ }^{1,2}$, Audrey Ridoux ${ }^{1,2}$, Arnaud Tiendrebeogo ${ }^{1,2}$, Murielle Salome 5 , Bernhard Hesse ${ }^{5}$, Delphine Vantelon ${ }^{6}$, Jérôme Rose ${ }^{4}$, Florence Canouï-Poitrine ${ }^{7,8}$, Jorge Boczkowski ${ }^{1,2}$, Sophie Lanone ${ }^{1,2}$, Christophe Delacourt $^{1,2, \dagger}$, and Jean-Claude Pairon ${ }^{1,2,9, \dagger^{*}}$

${ }^{1}$ Inserm, U955, Equipe 04, Créteil, France

${ }^{2}$ Université Paris Est Créteil, Faculté de Médecine, DHU A-TVB, IMRB, Créteil, France

${ }^{3}$ Laboratoire de Physique des Solides, CNRS, Univ. Paris-Sud, Université Paris-Saclay, Orsay, France

${ }^{4}$ CEREGE, Aix Marseille Université-CNRS-IRD-Collège de France, Aix-en-Provence, France ${ }^{5}$ European Synchrotron Radiation Facility, Grenoble, France

${ }^{6}$ Synchrotron SOLEIL, Gif-sur-Yvette, France

${ }^{7}$ Université Paris-Est Créteil (UPEC), DHU A-TVB, IMRB, EA 7376 CEpiA (Clinical Epidemiology And Ageing Unit), Créteil, F-94000, France

${ }^{8}$ AP-HP, Henri-Mondor Teaching Hospital, Public Health Department, Créteil, France

${ }^{9}$ Centre Hospitalier Intercommunal, Institut Santé-Travail Paris-Est, Créteil, France

${ }^{\dagger}$ These authors contributed equally to this work

*Corresponding author

Jean-Claude Pairon

Inserm U955 Equipe 04

Faculté de Médecine de Créteil

8 rue du Général Sarrail

94000 Créteil 
Phone: +33157022093

Email: jc.pairon@chicreteil.fr 


\section{Pulmonary exposure to metallic nanomaterials during pregnancy irreversibly impairs lung development of the offspring}

Due to the growing commercial applications of manufactured nanoparticles, toxicological studies on nanoparticles, especially during the critical window of development, are of major importance. The aim of the study was to assess the impact of respiratory exposure to metallic and metal oxide nanoparticles during pregnancy on lung development of the offspring and to determine the key parameters involved in lung alterations. Pregnant mice were exposed to weekly doses of $100 \mu \mathrm{g}$ (total dose $300 \mu \mathrm{g}$ ) of titanium dioxide $\left(\mathrm{TiO}_{2}\right)$, cerium oxide $\left(\mathrm{CeO}_{2}\right)$, silver $(\mathrm{Ag})$ nanoparticles or saline solution by nonsurgical intratracheal instillation. The offspring lungs were analyzed at different stages of lung development: fetal stage (gestational day 17.5), pulmonary alveolarization (post-delivery day 14.5), and lung maturity (post-delivery day 49.5). Regardless of the type of nanoparticle, maternal exposure during gestation induced long-lasting impairment of lung development of the offspring. This effect was accompanied by: i) decreased placental efficiency together with the presence of nanoparticles in placenta, ii) no increase of inflammatory mediators present in amniotic fluid, placenta or offspring lungs, and iii) decreased pulmonary expression of vascular endothelial growth factor $\alpha$ (VEGF- $\alpha$ ) and matrix metalloproteinase 9 (MMP-9) at the fetal stage, and fibroblast growth factor 18 (FGF-18) at the alveolarization stage. Respiratory exposure to metallic nanoparticles during pregnancy induces stereotyped impairment of lung development with a lasting effect in adult mice, independently of the chemical nature of the nanoparticle.

Keywords: nanoparticles; toxicology; lung development; pregnancy

Word count: 6933 


\section{Introduction}

Nanosciences and nanotechnologies are contributing to new applications in many fields, such as medicine (Smith et al., 2014, Paul et al., 2014), antibacterial materials (Lu et al., 2015), foods (Martirosyan and Schneider, 2014), cosmetics (Bowman et al., 2010), pigments (Shi et al., 2013), and electronics (Shen et al., 2014). Titanium dioxide $\left(\mathrm{TiO}_{2}\right)$, cerium oxide $\left(\mathrm{CeO}_{2}\right)$, and silver (Ag) nanoparticles (NPs) are among the most commonly manufactured NPs over the last decade. Pulmonary exposure of humans to these latter NPs is rapidly becoming unavoidable, raising several questions with regard to their safety and environmental impact. Experimentally, in vivo administration of $\mathrm{CeO}_{2} \mathrm{NPs}$ or $\mathrm{Ag}$ NPs into the airways of adult animals induces toxicological effects, such as oxidative stress (Srinivas et al., 2011), inflammation (Haberl et al., 2013), or lung remodeling (Ma et al., 2012).

The potential toxicological effects of pulmonary exposure to NPs during pregnancy, which is a critical window of development, has been poorly documented. Previous experimental studies have strongly suggested that NPs might impair fetal development, although most of these results were obtained using exposure conditions that were not relevant to usual human environmental exposure (Shimizu et al., 2009, Philbrook et al., 2011, Yamashita et al., 2011). Interestingly, the study by Hougaard et al. showed that inhalation of $\mathrm{TiO}_{2}$ NPs during pregnancy induced moderate neurobehavioral changes in the offspring (Hougaard et al., 2010). NPs can cross the placental barrier in pregnant mice after intravenous (Yamashita et al., 2011) or oral exposure (Philbrook et al., 2011) with demonstration of the presence of NPs in fetuses using TEM, and this translocation was linked to an impairment of normal growth and development of the fetuses. To our knowledge, no study has evaluated the impact of prenatal exposure to NPs on lung development. The aim of the present study was to evaluate the impact of exposure of pregnant mice to various intratracheally instilled NPs on the lung development of their offspring. Because NPs physicochemical characteristics are 
important determinants of their toxicological effects (Oberdorster, 2010), we used NPs with similar shapes and sizes, but with different physicochemical properties: $\mathrm{TiO}_{2} \mathrm{NPs}$ which are poorly soluble in biological media, $\mathrm{CeO}_{2} \mathrm{NPs}$ which have a high standard reduction potential (i.e. strong oxidant) and Ag NPs which dissolve through Ag oxidation. Our results show that maternal pulmonary exposure of mice to various NPs induced impairment of lung development with lasting effects in adult animals, regardless of the metallic or metal oxide NPs tested and regardless of the pulmonary response observed in the dams.

\section{Methods}

\section{Nanoparticle preparation and characterization}

$\mathrm{TiO}_{2}, \mathrm{CeO}_{2}$ and polyvinylpyrrolidone (PVP)-coated Ag nanopowders were purchased from Nanostructured and Amorphous Materials, Inc. (Houston, USA), Umicore, Nanograin ${ }^{\circledR}$ (Olen, Belgium) and nanoComposix, Inc. (Prague, Czech Republic), respectively. All nanoparticles were sold as having a spherical shape, $10 \mathrm{~nm}$ in diameter.

The various $\mathrm{NP}$ powders were suspended in $0.9 \% \mathrm{NaCl}$ at a concentration of 10 $\mathrm{mg} / \mathrm{ml}$. Before administration, NP suspensions were vortexed and sonicated in an ice bath at $37 \mathrm{kHz}$ for 10 minutes. The size distribution was assessed by transmission electron microscopy (TEM, JEOL JEM 1400, Peabody, USA) based on examination of more than 1,500 particles. Dynamic light scattering (DLS, NanoZS, Malvern, UK) was carried out to determine the zeta potential and hydrodynamic diameter of the various NPs. The crystallinity of $\mathrm{TiO}_{2} \mathrm{NPs}$ and $\mathrm{CeO}_{2}$ NPs was determined by X-ray diffraction (XRD, PANalytical X'Pert PRO, Limeil-Brévannes, France). The specific surface area of $\mathrm{TiO}_{2} \mathrm{NPs}$ was measured by a Micromeritics Flowsorb 2300 (Norcross, GA) using Brunauer Emmett Teller (BET) analysis. The specific surface area of $\mathrm{CeO}_{2}$ NPs and $\mathrm{Ag}$ NPs was estimated by TEM. To investigate possible Ag ion release from the Ag NPs suspension, an additional experiment was performed 
using Inductively Coupled Plasma Mass Spectrometry (ICP-MS, Perkin Elmer NexIon 300X, Waltham, USA). NPs endotoxin content was examined using the Limulus Amebocyte Lysate (LAL) kit QCL-1000 (Lonza, Basel, Switzerland) according to the manufacturer's instructions.

\section{Animals and treatments}

Twelve-week-old C57BL6/J mice (88 multiparous females and 44 males) were purchased from Janvier Laboratories (Le Genest-Saint-Isle, France). Multiparous females (with only 1 previous birth) were used in view of the high risk of cannibalism or abandonment by primiparous dams, as previously observed in the literature (Weber et al., 2013). Male and female mice were housed separately under controlled room temperatures $\left(22 \pm 2{ }^{\circ} \mathrm{C}\right)$, a 12 hour dark/light cycle with ad libitum access to food and water. Ethical approval for all animal experimentation was obtained from the local ethics committee $\left(\mathrm{N}^{\circ}\right.$ 12-104, ComEth Afssa/ENVA/UPEC, Maisons-Alfort, France). After one week of acclimatization, females were placed with males overnight $(12 \mathrm{~h})$. The following morning, mating was confirmed by the presence of a vaginal plug, and this time-point was considered to be gestational day 0.5 (GD 0.5). Pregnant mice were randomly divided into four groups ( $\mathrm{n} \geq 20$ per group): saline, TiO2 NPs, CeO2 NPs, and Ag NPs. Dams were housed 2 per cage, and cages had sawdust (changed weekly), cotton for nests, and a piece of wood to play. All procedures were conducted in accordance with the ethical standards of the local committee on animal experiments. At the time of exposure, pregnant mice were anesthetized by intramuscular injection (150 $\mu 1$ per mouse) of a mixture of $10 \%$ ketamine (Merial, Lyon, France) and 10\% xylazine (Bayer, Puteaux, France) in physiological saline. For the NP-exposed groups, $10 \mu 1$ of NPs suspended at $10 \mathrm{mg} / \mathrm{ml}$ were administered by non-surgical intratracheal instillation, three times during gestation (once a week: on GD 2.5, GD 9.5 and GD 16.5) using a 22 gauge 
catheter, while $10 \mu \mathrm{l}$ of vehicle alone was injected for the saline group. The total dose is 300 $\mu \mathrm{g}$, in the same order of magnitude as the dose previously used by Hougaard et al. (Hougaard et al., 2010). Pups were examined at various time-points during development, two days prior to spontaneous delivery (GD 17.5) for fetotoxicity analysis and measurement of metal concentrations in tissues, during lung alveolarization on post-delivery day 14.5 (PD 14.5) and when mice were adults (PD 49.5) for lung morphometry. The experimental protocol design is presented in supplementary Figure S1.

\section{Fetotoxicity}

To evaluate the potential fetotoxicity induced by NPs exposure, a C-section ( $\mathrm{n} \geq 6$ /group) was performed in dams at GD 17.5 and followed by rapid decapitation of fetuses. Uterine weight, number of fetuses, fetal weight ( $n \geq 37$ /group), fetal resorption (number of resorptions/total number of formed fetuses and resorptions) and placental efficiency (fetal weight/placental weight) were scored.

\section{Cytokine and chemokine determination in amniotic fluid and fetal lungs}

To further elucidate the toxicological mechanisms induced in pups after NP exposure during pregnancy, cytokine and chemokine concentrations were measured using the Luminex assay in the amniotic fluid of each pregnant dam and in the fetal lungs. The uterus was removed at GD 17.5 and $50 \mu 1$ of amniotic fluid were collected by direct insertion of a fine needle into the amniotic cavity. Immediately after harvesting, amniotic fluids were centrifuged $(8 \mathrm{~min}$ at $10,000 \mathrm{rpm})$ and the supernatants were stored at $-80{ }^{\circ} \mathrm{C}$. Fetal lungs were homogenized in $500 \mu \mathrm{l}$ of RIPA (Sigma-Aldrich, Saint-Louis, USA) lysis buffer with $10 \%$ of protease inhibitor cocktail (Sigma-Aldrich, Saint-Louis, USA) and stored at $-80{ }^{\circ} \mathrm{C}$. To evaluate inflammatory response or immune response, 26 cytokines or chemokines were 
measured in amniotic fluid ( $n=19$ /group) and fetal lungs $(n=10 /$ group $)$ in a total volume of $50 \mu 1$ using the Luminex assay (MCYTOMAG-70K-26, Merck Millipore, Saint-Quentin en Yvelines, France).

\section{Chemical analysis of placenta and fetal lungs}

In order to determine whether NPs can cross the placental barrier and have a direct effect in the developing fetus, chemical analysis was performed using ICP-MS. At GD 17.5, pregnant mice ( $n \geq 6$ /group) were sacrificed after being anesthetized, and the placenta ( $n \geq$ 10/group) and fetal lung ( $\mathrm{n} \geq 16 /$ group) were collected and stored at $-20{ }^{\circ} \mathrm{C}$ for ICP-MS analysis. Two placentas and 4 fetal lungs from each exposure group were pooled to determine dry organ weights. All tissues were digested with $1 \mathrm{ml}$ of $67-69 \%$ nitric acid (Plasmapure Plus SCP science, Courtaboeuf, France) for 1 hour at room temperature. During the digestion process, $0.5 \mathrm{ml}$ of $30 \%$ hydrogen peroxide (Plasmapure Plus SCP science), $1 \mathrm{ml}$ of $40 \%$ hydrofluoric acid (Plasmapure Plus SCP science) and $100 \mu \mathrm{l}$ of $96 \%$ sulfuric acid (Plasmapure Plus SCP science) were added to each sample. Samples were heated for 1.5 hour in a microwave chamber (UltraWAVE Milestone, Sorisole, Italy). Metal concentrations, expressed in $\mu \mathrm{g} / \mathrm{g}$ for each sample, were measured by ICP-MS.

The localization and speciation of $\mathrm{Ag}$ in the placenta and fetal lungs were assessed using micro X-ray fluorescence (micro-XRF) and micro X-ray absorption near edge structure (micro-XANES). Prior to measurements, tissues were fixed in $10 \%$ formalin overnight, dehydrated in a graded series of ethanol and isopropanol solution, and embedded in paraffin. Tissue sections $(15 \mu \mathrm{m}$ thick) were cut with a microtome and placed on thin window films used for XRF studies (Ultralene ${ }^{\circledR}, 4 \mu \mathrm{m}$ thick, SPEX SamplePrep).

XRF microscopy experiments were performed on ID21 beamline of the European Synchrotron Radiation Facility (ESRF, Grenoble, France) (Szlachetko et al., 2010). The X-ray beam was monochromated by a fixed-exit double-crystal $\operatorname{Si}(111)$ monochromator (Kohzu, 
Japan) and beam focalization was ensured by Kirkpatrick Baez (KB) mirrors allowing a beam size of $0.4 * 0.9 \mu \mathrm{m}^{2}$. Incident $\mathrm{X}$-ray energy of $6.7 \mathrm{keV}$ was chosen in order to excite the Ag Llines $\left(\mathrm{L}_{\alpha}=2.98\right.$ and $\left.\mathrm{L}_{\beta}=3.15 \mathrm{keV}\right)$. A silicon drift diode detector (SDD, Bruker) was used for fluorescence detection. Raster scans were performed across a chosen area of the sample preparation. Analysis of the X-ray fluorescence spectrum for each pixel can be used to plot a separate chemical map for each element. Analysis of XRF data was performed by batch processing using PyMca software (V.A. Solé, 2007).

XANES measurements were performed to determine the speciation of Ag NPs in the placenta. X-ray absorption spectra at the $\mathrm{AgL}_{3}$ edge $(3.351 \mathrm{keV})$ were collected at the LUCIA beamline of the SOLEIL synchrotron (Orsay, France) (Vantelon et al., 2016). The X-ray beam was monochromated with a $\mathrm{Si}(111)$ crystal and beam focalization was ensured by Kirkpatrick Baez $(\mathrm{KB})$ mirrors, allowing a beam size of $3^{*} 3 \mu \mathrm{m}^{2}$ on the sample. XANES data were obtained after performing standard procedures for pre-edge subtraction and normalization using IFEFFIT implemented in the ATHENA software package (Ravel and Newville, 2005).

\section{Lung morphometry}

Lung histology was analyzed in mothers and lung morphometry was measured in pups. Lungs were inflated with $10 \%$ prefiltered formalin at a pressure of $20 \mathrm{cmH}_{2} \mathrm{O}$ using a 22 gauge catheter, and were fixed overnight at room temperature. Lung volume was determined using the fluid displacement method (Franco et al., 2002). After fixation, tissues were dehydrated in a graded series of ethanol and isopropanol solution and embedded in paraffin. Five micrometer thick medial frontal sections of lungs were stained with hematoxylin and eosin (H\&E). An experimental pathologist reviewed all lung slides blindly with respect to the animal's treatment, and semi-quantitative evaluation of the inflammatory infiltrate (based on the presence of neutrophils and macrophages) was performed. Airway wall thickness was 
measured using imageJ software (National Institute of Health, USA) for evaluation of bronchial changes after intratracheal instillation of NPs in the lungs of the dams ( $\mathrm{n} \geq 4$ /group). The mean of 5 measures per complete bronchus was calculated, and 10 randomly selected bronchi per lung were evaluated. To assess the histopathological changes in pups, offspring were killed at PD 14.5 and PD 49.5 by exsanguination after aortic section. Lung sections of 10 pups randomly selected from each group were analyzed at the two different time points PD 14.5 and PD 49.5 using light microscopy (Axioplan 2, Oberkochen, Germany). Twenty randomly selected fields for each mouse (10 per lung) were studied at x10 magnification. Lung alveolarization defects were measured using two methods: mean linear intercept (MLI) and radial alveolar count (RAC). MLI was quantified by the methods described by Weibel (Weibel, 1966) and RAC was determined as previously reported (Cooney and Thurlbeck, 1982, Emery and Mithal, 1960).

\section{Genes and proteins expression in placenta and pup's lungs}

mRNA was isolated from whole-lung tissue homogenates using the RNeasy kit (Qiagen, Venlo, The Netherlands). Reverse transcription reactions were performed with Moloney Murine Leukemia Virus Reverse Transcriptase (MMLV, Life Technologies) according to the manufacturer's instructions. The expression of genes involved in inflammatory response in the placenta and in lung development (Table S1, supplementary data) was determined by RT-PCR using the Sybr Select Master Mix (Life Technologies) in a QuantStudio 6 Flex Real-Time PCR System (Life technologies). mRNA expression was normalized to that of HPRT1 and $18 \mathrm{~S}$ as a housekeeping gene. The sequences of the primers used are shown in Table S1 (supplementary data). Placental genes expression was performed in two layers of placenta, spongiotrophoblast and labyrinth zone. 
Pup's lungs were homogenized in $1 \mathrm{ml}$ of RIPA (Sigma-Aldrich, Saint-Louis, USA) lysis buffer with $10 \%$ protease inhibitor cocktail (Sigma-Aldrich, Saint-Louis, USA) and stored at $-80{ }^{\circ} \mathrm{C}$. MMP-9 and VEGF levels in lung homogenate were detected by ELISA according to the manufacturer's instructions and the optical density was determined at $450 \mathrm{~nm}$ with a microplate reader (Infinite ${ }^{\circledR} 200$ Pro, Tecan, Männedorf, Switzerland).

\section{Statistics}

Results of NP characterization were expressed as mean \pm standard error of the mean (s.e.m), while other results were expressed as median and interquartile due to non-normal distribution. As the data present a hierarchical structure (several offspring/placenta or several fetuses per dam) leading to a possible litter effect, we analyzed the relationship between exposure groups and fetal weight, placental weight, placental efficiency, cytokine and chemokine levels in amniotic fluid and fetal lungs, chemical assays in placenta and fetal lungs, XANES measurement and lung morphometry measurements and gene and protein expression in pup lungs using a mixed regression model (separately for each measure). The saline group constitued the reference group. Log-transformation was performed to normalize the distribution of biomarkers. The absence of any significant difference between the mixed model and the linear regression model (likelihood ratio test) indicated the absence of significant intra-class correlation (i.e litter effect), and the more parsimonious model (linear regression model) was used. The gender effect was tested by adjusting for gender in the regression model of lung morphometry measurements (at PD 14.5 and 49.5). All tests were two-tailed. A p-value less than 0.05 was considered statistically significant. Data were analyzed with GraphPad Prism 6.0 (La Jolla, CA) and STATA v13.0 (College Station, TX, USA). p-value less than 0.05 was considered statistically significant. Data were analyzed with GraphPad Prism 6.0 (La Jolla, CA) and STATA v13.0 (College Station, TX, USA). 


\section{Results}

\section{Nanoparticle characterization}

Transmission electron microscopy (TEM) images showed that all three NPs, i.e. $\mathrm{TiO}_{2}$ NPs, $\mathrm{CeO}_{2}$ NPs and Ag NPs, were spherical and had a similar primary particle size of $12.3 \pm 0.1,22.4 \pm 0.2$, and $10.4 \pm 0.1 \mathrm{~nm}$, respectively (Supplementary Figure S2). DLS analysis after suspending NPs in $\mathrm{NaCl}$ at a concentration of $10 \mathrm{mg} / \mathrm{mL}$, indicated an aggregation state for $\mathrm{TiO}_{2}$ and $\mathrm{CeO}_{2} \mathrm{NPs}$ that was higher (with aggregate size $>1000 \mathrm{~nm}$ ) than that for $\mathrm{Ag} \mathrm{NPs}$ (with aggregate size $<1000 \mathrm{~nm}$ ) (Supplementary Figure S3). NPs characteristics are summarized in Table 1. Silver ion dissolution from the Ag NPs suspension represented less than 3\% of total silver in the Ag NPs suspension, which suggested that the Ag NPs instilled into pregnant mice were in nanoparticle form.

\section{Fetotoxicity of nanoparticles}

Results of fetotoxicity analysis at gestational day 17.5 (GD 17.5) are shown in Figure 1. Uterine weight was not significantly modified after NPs treatment (Figure 1B). When compared to the control group, mice that received Ag NPs had significantly higher fetal resorption rates $(\mathrm{p}=0.004)$, while $\mathrm{TiO}_{2} \mathrm{NPs}$ and $\mathrm{CeO}_{2} \mathrm{NPs}$ treatment did not affect fetal resorption rates (Figure 1C, D). The number of living fetuses per litter was decreased in $\mathrm{Ag}$ groups (Figure 1E), and fetal weight (GD 17.5) was significantly decreased in the 3 NPexposed groups compared to the control group $(p<0.05)$. This decrease was much more marked for the Ag NPs group $(\mathrm{p}<0.001$ ) (Figure $1 \mathrm{~F}, \mathrm{G})$. Moreover, placental weight of $\mathrm{CeO}_{2}$ and Ag NPs groups was significantly higher than in the control group (Supplementary Figure S4). This was accompanied by a decrease of placental efficiency for all NP-exposed groups compared to the control group (Figure 1H). 


\section{Lung morphometric measurement}

Light microscopy evaluation of pup's lungs showed that pulmonary exposure to the three NPs during pregnancy induced significant and similar increases in the mean linear intercept (MLI) and decreases in the radial alveolar count (RAC) (Figure 2) and lung alveolar surface as compared to control animals (Table 2). Pulmonary exposure during pregnancy induced an increase of the alveolar space and a decrease of the number of alveoli, therefore globally leading to enlargement of the alveolar space. These phenomena were observed at the two stages of lung development studied (PD 14.5 and PD 49.5).

\section{Effects of NPs on pregnancy and dam lungs}

Maternal body weight of $\mathrm{TiO}_{2}$ NPs- and $\mathrm{CeO}_{2}$ NPs-treated mice did not differ from that of the saline group, and was slightly, but significantly decreased in Ag NPs-treated mice at GD 17.5 (Figure 1A). The number of inflammatory cells, such as macrophages and neutrophils, was increased in the lungs of pregnant mice after all NPs treatment compared to the control group. Dense areas observed on histological sections of dam lungs can be attributed to $\mathrm{TiO}_{2} \mathrm{NPs}$ and $\mathrm{CeO}_{2} \mathrm{NPs}$ aggregation (indicated as arrows). Such dense zones were present in the alveolar space, and were also seen in macrophages (Supplementary Figure S5A). Small airway wall thickness was measured as index of bronchial alteration and the results showed an increase of wall thickness in the lungs of pregnant mice after NPs exposure, which was significant in the $\mathrm{CeO}_{2}$ NPs and Ag NPs groups compared to the saline group (Supplementary Figure S5B).

\section{Cytokine content in amniotic fluid and fetal lungs}

Among the various cytokines and chemokines analyzed in amniotic fluid, the expression of vascular endothelial growth factor (VEGF) and macrophage inflammatory 
protein 2 (MIP-2), were significantly decreased in $\mathrm{CeO}_{2}$ and $\mathrm{Ag}$ NPs-exposed groups as compared to the control group (Supplementary Table S2). In addition, Granulocytemacrophage colony-stimulating factor (GM-CSF), interleukin 10 (IL-10) and interleukin 15 (IL-15) levels were decreased in the Ag NPs-exposed group as compared to the control group. The expression of monocyte chemoattractant protein-1 (MCP-1) significantly decreased in the $\mathrm{TiO}_{2}$ NPs-exposed group as compared to the control group. Only the expression of interferon gamma-induced protein 10 (IP-10) cytokine was increased in amniotic fluid in the Ag NPsexposed group as compared to the control group. No difference was observed for the other cytokines and chemokines examined. In fetal lung, cytokine and chemokine levels were similar for almost of them in the 3 NPs groups as compared to the saline group (Supplementary Table S3). GM-CSF protein expression was significantly decreased in the $\mathrm{CeO} 2 \mathrm{NPs}$ and Ag NPs-exposed groups. VEGF and IP-10 proteins expression was also significantly decreased in the Ag NPs group as compared to the control group. Conversely, granulocyte-colony stimulating factor (G-CSF) and IL-10 were significantly increased in the $\mathrm{TiO}_{2}$ NPs-exposed groups as compared to the control group. Moreover, IL-12 (p40) protein level was significantly increased in the $\mathrm{CeO}_{2}$ NPs-exposed group as compared to the control group.

\section{Biodistribution of nanoparticles and metal burden in placenta and fetal lung}

In accordance with exposure, titanium ( $\mathrm{Ti})$, cerium $(\mathrm{Ce})$ and silver $(\mathrm{Ag})$ burdens determined by ICP-MS were significantly higher in the placentas of the respective NPstreated groups as compared to the control group (Table 3). Analysis of metal burden levels in fetal lung at GD 17.5 revealed significant accumulation only for Ag (Table 3). To more precisely localize Ag NPs, X-Ray fluorescence (XRF) analysis was performed on placenta and fetal lungs of the Ag NPs group (Figure 3). Micro-XANES analysis performed on the 
same areas showed that Ag could be found in its nano form on the fetal side of the placenta, more particularly as large deposits on the chorionic plate. Ag was also localized as spots with random distribution in fetal lung.

\section{Expression of genes and proteins involved in lung development at GD 17.5 and PD 14.5}

Gene expression was measured in pup's lungs in order to elucidate the mechanisms involved in the alteration of lung development. During the fetal stage (GD 17.5), VEGF- $\alpha$ mRNA expression was significantly decreased $(\mathrm{p}<0.05)$ in $\mathrm{TiO}_{2} \mathrm{NPs}-$ and $\mathrm{CeO}_{2} \mathrm{NPs}$-exposed groups as compared to the control group (Figure 4A), whereas MMP-9 mRNA expression was decreased $(\mathrm{p}<0.05)$ in all 3 NPs-exposed groups (Figure 4B). At the alveolarization stage (PD 14.5), FGF-18 mRNA expression was significantly decreased $(\mathrm{p}<0.05)$ in the 3 NPstreated groups as compared to the control group (Figure S6A). Expression of other genes involved in alveolarization, such as FGF-R3, FGF-R4 and adrenomedullin, was not modified by NPs exposure (Figure S6 B, C and D). VEGF protein expression in pup lungs at PD 14.5 was significantly decreased in the $\mathrm{CeO}_{2}$ NPs- and $\mathrm{Ag}$ NPs-exposed groups as compared to the control group (Figure 4C). MMP-9 expression was similar in the 3 NPs-exposed groups and in the control group (Figure 4D). 


\section{Discussion}

The main results of this study are that pulmonary exposure during pregnancy to metallic and metal oxide NPs $\left(\mathrm{TiO}_{2}, \mathrm{CeO}_{2}\right.$ and $\left.\mathrm{Ag}\right)$ with similar shapes and primary particle diameters, but with different solubility and surface properties, led to a similar and long-lasting impairment of lung development of the offspring. This effect was associated with: i) a significant decrease in fetal weight and placental efficiency index associated with the presence of the three NPs in the placenta, ii) the absence of any significant amniotic or fetal lung inflammation, and iii) a significant decrease in VEGF mRNA and protein levels in both amniotic fluid and pup lungs. Overall, to the best of our knowledge, these results provide the first experimental evidence of impairment of offspring pulmonary development after respiratory exposure to NPs during gestation. The underlying mechanisms probably involve placental insufficiency secondary to the presence of NPs in this organ with ensuing down regulation of critical mediators of lung development without any amniotic fluid or fetal lung inflammation.

Different mechanisms by which pulmonary exposure to NPs during pregnancy could induce lung impairment in the offspring were investigated in the present study. First, we hypothesized that maternal exposure to NP may induce pulmonary inflammation, resulting in a fetal inflammatory condition and delayed lung development, as previously reported (Kramer et al., 2009). Histological examination of the lungs of exposed pregnant mice demonstrated that NP exposure induced pulmonary inflammation in the 3 groups of NP-treated animals. This type of pulmonary inflammation response to respiratory exposure to NP has been previously reported in the literature (Seiffert et al., 2015, Srinivas et al., 2011, Hougaard et al., 2010). However, in our study, no inflammatory response was detected in the amniotic fluid, placenta (Figure S7, supplementary data) and lungs of fetuses from dams exposed to NPs. In particular, no increase in IL- 6 and TNF- $\alpha$ levels was observed in amniotic fluid. This could be 
considered as striking as such increase has been described as predictive of fetal inflammatory response and adverse neonatal outcome (Kunze et al., 2016). However, this particular study was performed in a very different context (i.e. human with fetal inflammatory response syndrome, due to intrauterine inflammation and/or infection), which could largely influence the results. In some experimental studies, a significant increase in IL- 6 and TNF- $\alpha$ levels was described. However, this was observed in adults mice lungs only after pulmonary exposure to high doses of particles $\left(\mathrm{TiO}_{2}\right.$, diesel exhaust) or very inflammogenic particles (Quartz) (Saber et al., 2006, Roursgaard et al., 2010, Roursgaard et al., 2011). Finally, although the mother's lungs appear as inflammatory, this compartment is far from the intrauterine environment. This, therefore, may explain the lack of increase of IL- 6 and TNF- $\alpha$ levels that we observed in the fetal compartment. Inflammation of dam lungs exposed to NPs therefore does not appear to be the underlying mechanism contributing to lung impairment in the offspring.

Second, placental insufficiency is known to be strongly associated with fetal growth restriction (FGR), fetal death and inhibition of fetal development (William W. Hay, 2001, Rosenberg, 2008). Moreover, it has been shown that FGR has long-term effects on postnatal lung structure (Maritz et al., 2004). In our study, we showed that exposure to NPs during pregnancy decreased placental efficiency, leading to fetal death and FGR. FGR could be directly related to translocation of NPs from dam lungs to pups. Fetal death and FGR have been demonstrated after intravenous administration of high doses of NP in pregnant mice (Yamashita et al., 2011). In our study, ICP-MS and XRD analysis showed the presence of Ti, $\mathrm{Ce}$ and $\mathrm{Ag}$ elements in the placenta after exposure to NPs during pregnancy. Moreover, XANES analysis revealed that silver was present in the placenta in its nano form. In view of the lower solubility of $\mathrm{TiO}_{2} \mathrm{NPs}$ and $\mathrm{CeO}_{2} \mathrm{NPs}$, we can therefore assume that the 3 NPs used in this study were present in their nanoparticle form in the placenta, and could be involved in inflammation-independent decreased placental efficiency with ensuing FGR and impairment 
of pup lung development. Ag element was also identified in the fetal lung, suggesting that Ag may cross the placental barrier and may have a direct effect on the developing fetus, although the presence of the nanoparticle form of $\mathrm{Ag}$ in fetal lung cannot be formally confirmed. $\mathrm{Ag}$ element did not appear to be distributed equally in the fetal organs, as Ag was mainly present in the liver and kidneys of the fetuses. Moreover, Ag was also present at a significant degree in the fetal brain (Supplementary Table S4). The form of Ag (nano or ionic) can modify its biodistribution in the organs, as the study by Charehsaz et al. showed that Ag biodistribution in the fetus, after oral gavage during pregnancy of different forms of $\mathrm{Ag}$ (nano or ionic), differed according to the two $\mathrm{Ag}$ species. Ag element from the $\mathrm{AgNO}_{3}$ group was detected in the lungs and plasma of the fetuses, whereas in the Ag NPs group, elevated levels of Ag were only observed in the fetal kidney (Charehsaz et al., 2016). Differences in the biodistribution of the 3 NPs could be explained by the fact that $\mathrm{TiO}_{2}$ and $\mathrm{CeO}_{2} \mathrm{NPs}$ had a higher aggregation state than Ag NPs, as shown in TEM images and confirmed by DLS analysis. The capacity of NPs to cross the placenta has been previously reported via other routes of administration (Yamashita et al., 2011, Austin et al., 2015). However, the hypothesis of a direct effect of NPs on lung development does not appear to be relevant for all types of NPs because, in the other two exposure groups, no excess of $\mathrm{Ti}$ and Ce elements was detected in fetal lung although the degree of lung impairment was similar to that observed in the Ag NPs-treated group. Therefore, our main hypothesis is that administration of NPs in pregnant mice is followed by an effect on the placenta with a subsequent effect on the respiratory development of the offspring, independently of the size of aggregates observed with NPs.

Various signaling pathways may be involved in the alteration of pup lungs development secondary to placenta insufficiency in the present study. We first focused on VEGF, which is involved in microvascular lung development (Mullassery and Smith, 2015). The results showed that VEGF expression was significantly decreased in amniotic fluid and 
also in pup lungs at GD 17.5 and PD 14.5 after treatment of dams with the three NPs. We also observed decreased VEGF gene expression in the placenta, more particularly in the spongiotrophoblast layer for $\mathrm{TiO}_{2}$ and $\mathrm{CeO}_{2}$ NPs (Figure S7, supplementary data). This result is in accordance with the recent study by Valentino et al., who observed a decrease in placental blood flow following maternal exposure to diluted diesel engine in a rabbit model (Valentino et al., 2016) but also with other studies in mice (Yamashita et al., 2011, Qi et al., 2014). Decreased placental blood flow may affect maternal-fetal exchange and consequently fetal growth. In this context, the decreased VEGF observed in pup lungs could be due to the presence of NPs in this organ. However, only the presence of Ag NPs was observed in pup lungs, while similar degrees of decreased VEGF and lung impairment were observed in the 3 groups of pups born to dams exposed to NPs. Decreased VEGF expression could be the mechanism leading to impairment of the lungs, as it has been demonstrated that an inhibitor of the VEGF receptor KDR/flk-1 was associated with hypoalveolarization (Jakkula et al., 2000). Moreover, inhibition of VEGF signaling after intra-amniotic treatment with Flt-1 may disrupt lung growth and contribute to an increased risk of bronchopulmonary dysplasia (Tang et al., 2012). Analysis of other genes involved in lung development showed that MMP-9 and FGF-18 were similarly downregulated in the 3 groups of pups. These findings are in accordance with those of a study that investigated pulmonary exposure of newborn mice to $\mathrm{TiO}_{2}$ NPs, which showed decreased-expression of VEGF- $\alpha$ (Ambalavanan et al., 2013). In contrast, the present study provides the first evidence of decreased FGF-18 mRNA expression in mice exposed to NPs during gestation. We also observed decreased expression of MMP-9, while Ambalavanan et al. reported increased MMP-9 expression in newborn mice exposed to $\mathrm{TiO}_{2}$ NP (Ambalavanan et al., 2013). However, in their study, increased MMP-9 expression was observed in the context of a pro-inflammatory response that was not observed in the present study. 
Certain methodological aspects of our study need to be discussed. Firstly, animals were exposed to NP via intratracheal instillation instead of aerosol exposure, which is more relevant in terms of human exposure to manufactured NP. However, intratracheal instillation has been reported to provide similar results in terms of pulmonary exposure to nanomaterials compared to aerosol exposure and similar results in terms of inflammatory respiratory response (Morimoto et al., 2016). Mice were exposed weekly to different NPs to ensure exposure of fetuses throughout gestation. We therefore cannot evaluate specific phases of gestation. Another limitation of this study could be the use of a single high dose of NP. We chose this strategy because this study was designed to demonstrate the concept of deleterious effects in the offspring following maternal lung exposure to NP. Nevertheless, the dose chosen was of the same order of magnitude as the dose previously used by Hougaard et al. (Hougaard et al., 2010) and was also relevant to occupational exposure to metallic NP reported in some occupational settings (Lee et al., 2011). Indeed, based on a rough estimate of an equivalent of inhaled aerosol applying the equation proposed by Présumé et al. (Presume et al., 2016), the equivalent inhaled concentration received by the mice in our study was 2.8 $\mathrm{mg} / \mathrm{m}^{3}$ for an exposure of $8 \mathrm{~h} /$ day for 5 days. Finally, we performed complete physicochemical characterization of the 3 three NPs and analyzed several stages of lung development (fetal stage, alveolarization stage and adult lung), to examine persistence of the effects of in utero exposure to NPs. In humans, it has been demonstrated that children with bronchopulmonary dysplasia may be at increased risk of lung diseases such as emphysema, asthma and Chronic Obstructive Pulmonary Disease-like phenotype later in life (Wong et al., 2008, Baraldi and Filippone, 2007). These findings also raise the question of whether, like in utero exposure to cigarette smoke (Wu et al., 2009, Hollams et al., 2014, Drummond et al., 2016), maternal exposure to NPs during pregnancy could increase the risk of developing lung diseases such as asthma or COPD in adulthood. The clinical relevance of our findings may 
therefore extend beyond the scope of histological abnormalities and indicate an increased susceptibility to develop other respiratory tract diseases. Specific complementary experiments should be conducted in this context.

\section{Conclusion}

In conclusion, the present study provides the first evidence that respiratory exposure during pregnancy leads to long-lasting lung impairment in the offspring. In view of the growing use of these nanoparticles, this result raises concerns for public health and pregnant women and their developing fetus particularly for those at high risk of occupational or domestic exposure.

\section{Acknowledgments}

We thank Dr. V. Cohignac for her help in the animal experiments. The expert technical assistance of M. Surenaud is also gratefully acknowledged. Special thanks to Dr. P. Andujar, Dr. P. Launois, S. Rouziere, Dr. T. Fournier, Dr. PH. Jarreau, S. Valentino, Dr. P. Chavatte Palmer, Dr. A. Tarrade and Dr. J. Tran Van Nhieu for their helpful comments.

\section{Funding}

This work was carried out in the framework of the Labex SERENADE (ANR-11LABX-0064) and A*MIDEX project (ANR-11-IDEX-0001-02), funded by the "Investissements d'Avenir" French Government program managed by the French National Research Agency (ANR). DHU ATV-B.

\section{Declaration of interests}

The authors declare that they have no competing interests.

\section{Ethics approval and consent to participate}


Ethical approval for all animal experimentation was obtained from the local ethics committee ( $\mathrm{N}^{\circ}$ 12-104, ComEth Afssa/ENVA/UPEC, Maisons-Alfort, France) 


\section{References}

AMBALAVANAN, N., STANISHEVSKY, A., BULGER, A., HALLORAN, B., STEELE, C., VOHRA, Y. \& MATALON, S. 2013. Titanium oxide nanoparticle instillation induces inflammation and inhibits lung development in mice. Am J Physiol Lung Cell Mol Physiol, 304, L152-61.

AUSTIN, C. A., HINKLEY, G. K., MISHRA, A. R., ZHANG, Q., UMBREIT, T. H., BETZ, M. W., B, E. W., CASEY, B. J., FRANCKE-CARROLL, S., HUSSAIN, S. M., ROBERTS, S. M., BROWN, K. M. \& GOERING, P. L. 2015. Distribution and accumulation of $10 \mathrm{~nm}$ silver nanoparticles in maternal tissues and visceral yolk sac of pregnant mice, and a potential effect on embryo growth. Nanotoxicology, 1-8.

BARALDI, E. \& FILIPPONE, M. 2007. Chronic lung disease after premature birth. N Engl J Med, 357, 1946-55.

BOWMAN, D. M., VAN CALSTER, G. \& FRIEDRICHS, S. 2010. Nanomaterials and regulation of cosmetics. Nat Nanotechnol, 5, 92.

CHAREHSAZ, M., HOUGAARD, K. S., SIPAHI, H., EKICI, A. I., KASPAR, C., CULHA, M., BUCURGAT, U. U. \& AYDIN, A. 2016. Effects of developmental exposure to silver in ionic and nanoparticle form: A study in rats. Daru, 24, 24.

CHAUDHURY, K., BABU, K. N., SINGH, A. K., DAS, S., KUMAR, A. \& SEAL, S. 2013. Mitigation of endometriosis using regenerative cerium oxide nanoparticles. Nanomedicine, 9, 439-48.

COONEY, T. P. \& THURLBECK, W. M. 1982. The radial alveolar count method of Emery and Mithal: a reappraisal 2--intrauterine and early postnatal lung growth. Thorax, 37, 580-3.

DRUMMOND, D., BARAVALLE-EINAUDI, M., LEZMI, G., VIBHUSHAN, S., FRANCO-MONTOYA, M. L., HADCHOUEL, A., BOCZKOWSKI, J. \& DELACOURT, C. 2016. Combined Effects of in Utero and Adolescent Tobacco Smoke Exposure on Lung Function in C57BI/6J Mice. Environ Health Perspect.

EMERY, J. L. \& MITHAL, A. 1960. The number of alveoli in the terminal respiratory unit of man during late intrauterine life and childhood. Arch Dis Child, 35, 544-7.

FRANCO, M. L., WASZAK, P., BANALEC, G., LEVAME, M., LAFUMA, C., HARF, A. \& DELACOURT, C. 2002. LPS-induced lung injury in neonatal rats: changes in gelatinase activities and consequences on lung growth. Am J Physiol Lung Cell Mol Physiol, 282, L491-500.

HABERL, N., HIRN, S., WENK, A., DIENDORF, J., EPPLE, M., JOHNSTON, B. D., KROMBACH, F., KREYLING, W. G. \& SCHLEH, C. 2013. Cytotoxic and proinflammatory effects of PVP-coated silver nanoparticles after intratracheal instillation in rats. Beilstein J Nanotechnol, 4, 933-40.

HOLLAMS, E. M., DE KLERK, N. H., HOLT, P. G. \& SLY, P. D. 2014. Persistent effects of maternal smoking during pregnancy on lung function and asthma in adolescents. Am J Respir Crit Care Med, 189, 401-7.

HOUGAARD, K. S., JACKSON, P., JENSEN, K. A., SLOTH, J. J., LOSCHNER, K., LARSEN, E. H., BIRKEDAL, R. K., VIBENHOLT, A., BOISEN, A. M., WALLIN, H. \& VOGEL, U. 2010. Effects of prenatal exposure to surface-coated nanosized titanium dioxide (UV-Titan). A study in mice. Part Fibre Toxicol, 7, 16.

JAKKULA, M., LE CRAS, T. D., GEBB, S., HIRTH, K. P., TUDER, R. M., VOELKEL, N. F. \& ABMAN, S. H. 2000. Inhibition of angiogenesis decreases alveolarization in the developing rat lung. Am J Physiol Lung Cell Mol Physiol, 279, L600-7.

KRAMER, B. W., KALLAPUR, S., NEWNHAM, J. \& JOBE, A. H. 2009. Prenatal inflammation and lung development. Semin Fetal Neonatal Med, 14, 2-7.

KUNZE, M., KLAR, M., MORFELD, C. A., THORNS, B., SCHILD, R. L., MARKFELD-EROL, F., RASENACK, R., PROEMPELER, H., HENTSCHEL, R. \& SCHAEFER, W. R. 2016. Cytokines in noninvasively obtained amniotic fluid as predictors of fetal inflammatory response syndrome. Am J Obstet Gynecol.

LEE, J. H., KWON, M., JI, J. H., KANG, C. S., AHN, K. H., HAN, J. H. \& YU, I. J. 2011. Exposure assessment of workplaces manufacturing nanosized TiO2 and silver. Inhal Toxicol, 23, 226-36. 
LU, Z., XIAO, J., WANG, Y. \& MENG, M. 2015. In situ synthesis of silver nanoparticles uniformly distributed on polydopamine-coated silk fibers for antibacterial application. J Colloid Interface Sci, 452, 8-14.

MA, J. Y., MERCER, R. R., BARGER, M., SCHWEGLER-BERRY, D., SCABILLONI, J., MA, J. K. \& CASTRANOVA, V. 2012. Induction of pulmonary fibrosis by cerium oxide nanoparticles. Toxicol Appl Pharmacol, 262, 255-64.

MARITZ, G. S., COCK, M. L., LOUEY, S., SUZUKI, K. \& HARDING, R. 2004. Fetal growth restriction has long-term effects on postnatal lung structure in sheep. Pediatr Res, 55, 287-95.

MARTIROSYAN, A. \& SCHNEIDER, Y. J. 2014. Engineered nanomaterials in food: implications for food safety and consumer health. Int J Environ Res Public Health, 11, 5720-50.

MORIMOTO, Y., IZUMI, H., YOSHIURA, Y., TOMONAGA, T., LEE, B. W., OKADA, T., OYABU, T., MYOJO, T., KAWAI, K., YATERA, K., SHIMADA, M., KUBO, M., YAMAMOTO, K., KITAJIMA, S., KURODA, E., HORIE, M., KAWAGUCHI, K. \& SASAKI, T. 2016. Comparison of pulmonary inflammatory responses following intratracheal instillation and inhalation of nanoparticles. Nanotoxicology, 10, 607-18.

MULLASSERY, D. \& SMITH, N. P. 2015. Lung development. Semin Pediatr Surg, 24, 152-5.

OBERDORSTER, G. 2010. Safety assessment for nanotechnology and nanomedicine: concepts of nanotoxicology. J Intern Med, 267, 89-105.

PAUL, G., PRADO, Y., DIA, N., RIVIERE, E., LAURENT, S., ROCH, M., ELST, L. V., MULLER, R. N., SANCEY, L., PERRIAT, P., TILLEMENT, O., MALLAH, T. \& CATALA, L. 2014. Mn(II)-containing coordination nanoparticles as highly efficient $T(1)$ contrast agents for magnetic resonance imaging. Chem Commun (Camb), 50, 6740-3.

PHILBROOK, N. A., WINN, L. M., AFROOZ, A. R., SALEH, N. B. \& WALKER, V. K. 2011. The effect of $\mathrm{TiO}(2)$ and $\mathrm{Ag}$ nanoparticles on reproduction and development of Drosophila melanogaster and CD-1 mice. Toxicol Appl Pharmacol, 257, 429-36.

PRESUME, M., SIMON-DECKERS, A., TOMKIEWICZ-RAULET, C., LE GRAND, B., TRAN VAN NHIEU, J., BEAUNE, G., DURUPHTY, O., DOUCET, J., COUMOUL, X., PAIRON, J. C., BOCZKOWSKI, J., LANONE, S. \& ANDUJAR, P. 2016. Exposure to metal oxide nanoparticles administered at occupationally relevant doses induces pulmonary effects in mice. Nanotoxicology, 10, 15351544.

QI, W., BI, J., ZHANG, X., WANG, J., WANG, J., LIU, P., LI, Z. \& WU, W. 2014. Damaging effects of multiwalled carbon nanotubes on pregnant mice with different pregnancy times. Sci Rep, 4, 4352.

RAVEL, B. \& NEWVILLE, M. 2005. ATHENA, ARTEMIS, HEPHAESTUS: data analysis for X-ray absorption spectroscopy using IFEFFIT. J Synchrotron Radiat, 12, 537-41.

ROSENBERG, A. 2008. The IUGR newborn. Semin Perinatol, 32, 219-24.

ROURSGAARD, M., JENSEN, K. A., POULSEN, S. S., JENSEN, N. E., POULSEN, L. K., HAMMER, M., NIELSEN, G. D. \& LARSEN, S. T. 2011. Acute and subchronic airway inflammation after intratracheal instillation of quartz and titanium dioxide agglomerates in mice. ScientificWorldJournal, 11, 801-25.

ROURSGAARD, M., POULSEN, S. S., POULSEN, L. K., HAMMER, M., JENSEN, K. A., UTSUNOMIYA, S., EWING, R. C., BALIC-ZUNIC, T., NIELSEN, G. D. \& LARSEN, S. T. 2010. Time-response relationship of nano and micro particle induced lung inflammation. Quartz as reference compound. Hum Exp Toxicol, 29, 915-33.

SABER, A. T., JACOBSEN, N. R., BORNHOLDT, J., KJAER, S. L., DYBDAHL, M., RISOM, L., LOFT, S., VOGEL, U. \& WALLIN, H. 2006. Cytokine expression in mice exposed to diesel exhaust particles by inhalation. Role of tumor necrosis factor. Part Fibre Toxicol, 3, 4.

SEIFFERT, J., HUSSAIN, F., WIEGMAN, C., LI, F., BEY, L., BAKER, W., PORTER, A., RYAN, M. P., CHANG, Y., GOW, A., ZHANG, J., ZHU, J., TETLEY, T. D. \& CHUNG, K. F. 2015. Pulmonary toxicity of instilled silver nanoparticles: influence of size, coating and rat strain. PLoS One, 10, e0119726.

SHEIKPRANBABU, S., KALISHWARALAL, K., VENKATARAMAN, D., EOM, S. H., PARK, J. \& GURUNATHAN, S. 2009. Silver nanoparticles inhibit VEGF-and IL-1beta-induced vascular 
permeability via Src dependent pathway in porcine retinal endothelial cells. $J$

Nanobiotechnology, 7, 8.

SHEN, W., ZHANG, X., HUANG, Q., XU, Q. \& SONG, W. 2014. Preparation of solid silver nanoparticles for inkjet printed flexible electronics with high conductivity. Nanoscale, 6, 1622-8.

SHI, H., MAGAYE, R., CASTRANOVA, V. \& ZHAO, J. 2013. Titanium dioxide nanoparticles: a review of current toxicological data. Part Fibre Toxicol, 10, 15

SHIMIZU, M., TAINAKA, H., OBA, T., MIZUO, K., UMEZAWA, M. \& TAKEDA, K. 2009. Maternal exposure to nanoparticulate titanium dioxide during the prenatal period alters gene expression related to brain development in the mouse. Part Fibre Toxicol, 6, 20.

SMITH, B. R., GHOSN, E. E., RALLAPALLI, H., PRESCHER, J. A., LARSON, T., HERZENBERG, L. A. \& GAMBHIR, S. S. 2014. Selective uptake of single-walled carbon nanotubes by circulating monocytes for enhanced tumour delivery. Nat Nanotechnol, 9, 481-7.

SRINIVAS, A., RAO, P. J., SELVAM, G., MURTHY, P. B. \& REDDY, P. N. 2011. Acute inhalation toxicity of cerium oxide nanoparticles in rats. Toxicol Lett, 205, 105-15.

SZLACHETKO, J., COTTE, M., MORSE, J., SALOME, M., JAGODZINSKI, P., DOUSSE, J. C., HOSZOWSKA, J., KAYSER, Y. \& SUSINI, J. 2010. Wavelength-dispersive spectrometer for X-ray microfluorescence analysis at the X-ray Microscopy beamline ID21 (ESRF). J Synchrotron Radiat, 17, 400-8.

TANG, J. R., KARUMANCHI, S. A., SEEDORF, G., MARKHAM, N. \& ABMAN, S. H. 2012. Excess soluble vascular endothelial growth factor receptor-1 in amniotic fluid impairs lung growth in rats: linking preeclampsia with bronchopulmonary dysplasia. Am J Physiol Lung Cell Mol Physiol, 302, L36-46.

V.A. SOLÉ, E. P., M. COTTE, PH. WALTER, J. SUSINI 2007. A multiplatform code for the analysis of energy-dispersive X-ray fluorescence spectra. Spectrochimica Acta, 62, 63-68.

VALENTINO, S. A., TARRADE, A., AIOUN, J., MOURIER, E., RICHARD, C., DAHIREL, M., ROUSSEAURALLIARD, D., FOURNIER, N., AUBRIERE, M. C., LALLEMAND, M. S., CAMOUS, S., GUINOT, M., CHARLIER, M., AUJEAN, E., AL ADHAMI, H., FOKKENS, P. H., AGIER, L., BOERE, J. A., CASSEE, F. R., SLAMA, R. \& CHAVATTE-PALMER, P. 2016. Maternal exposure to diluted diesel engine exhaust alters placental function and induces intergenerational effects in rabbits. Part Fibre Toxicol, 13, 39.

VANTELON, D., TRCERA, N., ROY, D., MORENO, T., MAILLY, D., GUILET, S., METCHALKOV, E., DELMOTTE, F., LASSALLE, B., LAGARDE, P. \& FLANK, A. M. 2016. The LUCIA beamline at SOLEIL. J Synchrotron Radiat, 23, 635-40.

WEBER, E. M., ALGERS, B., WURBEL, H., HULTGREN, J. \& OLSSON, I. A. 2013. Influence of strain and parity on the risk of litter loss in laboratory mice. Reprod Domest Anim, 48, 292-6.

WEIBEL, E. R. 1966. [Morphometric studies on the growth of gas exchange capacity of the rat lung]. Helv Physiol Pharmacol Acta, 24, C56-9.

WILLIAM W. HAY, J., PATTI J. THUREEN, MARIANNE S. ANDERSON 2001. Intrauterine growth restriction. Neo Reviews, 2, 129-138.

WONG, P. M., LEES, A. N., LOUW, J., LEE, F. Y., FRENCH, N., GAIN, K., MURRAY, C. P., WILSON, A. \& CHAMBERS, D. C. 2008. Emphysema in young adult survivors of moderate-to-severe bronchopulmonary dysplasia. Eur Respir J, 32, 321-8.

WU, Z. X., HUNTER, D. D., KISH, V. L., BENDERS, K. M., BATCHELOR, T. P. \& DEY, R. D. 2009. Prenatal and early, but not late, postnatal exposure of mice to sidestream tobacco smoke increases airway hyperresponsiveness later in life. Environ Health Perspect, 117, 1434-40.

YAMASHITA, K., YOSHIOKA, Y., HIGASHISAKA, K., MIMURA, K., MORISHITA, Y., NOZAKI, M., YOSHIDA, T., OGURA, T., NABESHI, H., NAGANO, K., ABE, Y., KAMADA, H., MONOBE, Y., IMAZAWA, T., AOSHIMA, H., SHISHIDO, K., KAWAI, Y., MAYUMI, T., TSUNODA, S., ITOH, N., YOSHIKAWA, T., YANAGIHARA, I., SAITO, S. \& TSUTSUMI, Y. 2011. Silica and titanium dioxide nanoparticles cause pregnancy complications in mice. Nat Nanotechnol, 6, 321-8. 
Tables

Table 1: Nanoparticles characteristics

\begin{tabular}{|c|c|c|c|c|c|c|c|c|}
\hline Composition & Coating & $\begin{array}{l}\text { Crystalline } \\
\text { surface }\end{array}$ & Shape & $\begin{array}{l}\text { Dimensions } \\
(\mathrm{nm})\end{array}$ & $\begin{array}{c}\text { Specific } \\
\text { surface area } \\
2 \\
\left(\mathrm{~m}^{2} / \mathrm{g}\right)\end{array}$ & $\begin{array}{c}\text { Zeta } \\
\text { potential } \\
\mathrm{pH} 7(\mathrm{mV})\end{array}$ & $\begin{array}{l}\text { Hydrodynamic } \\
\text { diameter }(\mathrm{nm})\end{array}$ & $\begin{array}{c}\text { Endotoxin } \\
\text { level }\end{array}$ \\
\hline $\mathrm{TiO}_{2}$ & No & Anatase & Spherical & $\begin{array}{r}12.3 \\
\pm 0.1\end{array}$ & $96 \pm 2.3$ & $3.7 \pm 0.2$ & 1280 & 0 \\
\hline $\mathrm{CeO}_{2}$ & No & Cerianite & Spherical & $\begin{array}{r}22.4 \\
\pm 0.2\end{array}$ & $42 \pm 0.5$ & $9.5 \pm 0.6$ & 1480 & 0 \\
\hline $\mathrm{Ag}$ & PVP & Amorphous & Spherical & $\begin{array}{r}10.4 \\
\pm 0.1\end{array}$ & $60 \pm 0.6$ & $-6.2 \pm 0.1$ & 38 and 720 & 0 \\
\hline
\end{tabular}

Nanoparticles characteristics: shape and size were determined by transmission electron microscopy (TEM), crystallinity of $\mathrm{TiO}_{2} \mathrm{NPs}$ and $\mathrm{CeO}_{2} \mathrm{NPs}$ was determined by X-ray diffractometer, specific surface area was estimated by TEM or using Brunauer Emmett Teller analysis, zeta potential and hydrodynamic diameter was determined by dynamic light scattering, NPs endotoxin content was examined using the Limulus Amebocyte Lysate test. $\mathrm{TiO}_{2}$ : Titanium dioxide, $\mathrm{CeO}_{2}$ : Cerium dioxide, Ag: Silver, PVP: polyvinylpyrrolidone. 
Table 2: Lung volume and lung morphometry in the offspring at post-delivery day 14.5 and 49.5

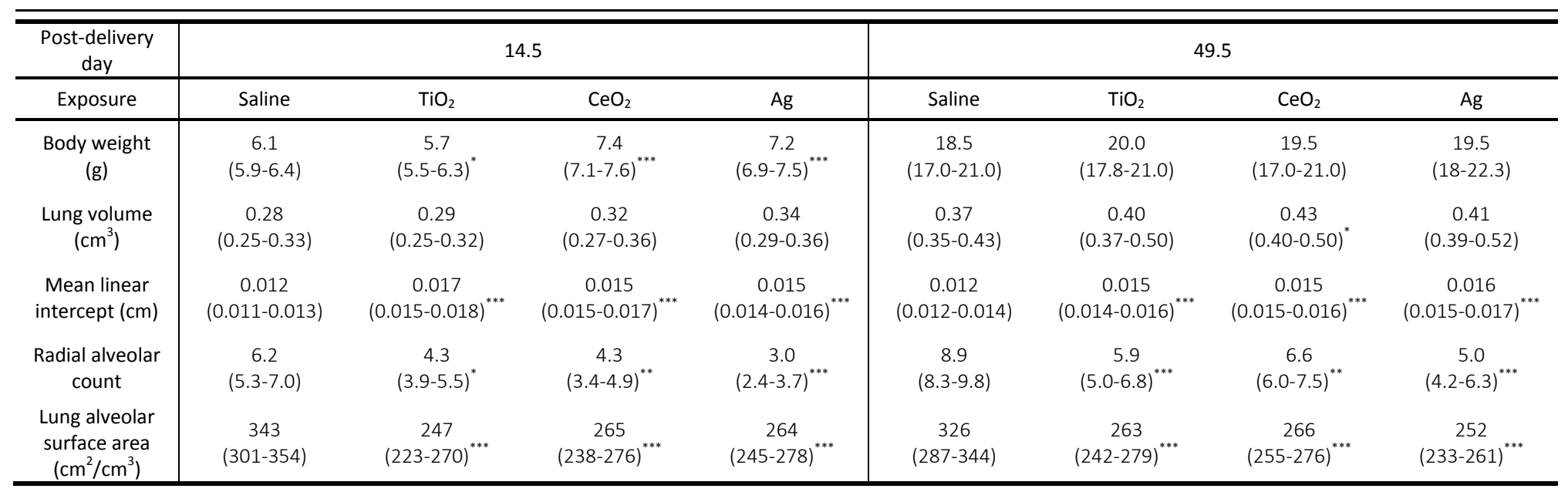

$\mathrm{n}=10$ /group. Results are expressed as the median and interquartile range. Statistically significant differences between exposed and control groups are indicated as $*: \mathrm{p}<0.05, * *: \mathrm{p}<0.01, * * *: \mathrm{p}<0.001$. Linear regression model adjusted for sex.

$\mathrm{TiO}_{2}$ : Titanium dioxide, $\mathrm{CeO}_{2}$ : Cerium dioxide, $\mathrm{Ag}$ : Silver. 
Table 3: Element detection in the placenta and fetal lung at GD 17.5 using ICP-MS

\begin{tabular}{|c|c|c|c|c|}
\hline \multirow[b]{3}{*}{ 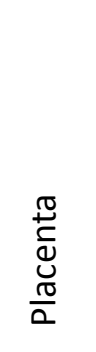 } & \multirow[b]{2}{*}{ Exposure } & \multicolumn{3}{|c|}{ Element concentration $(\mu \mathrm{g} / \mathrm{g})$} \\
\hline & & $\mathrm{Ti}$ & $\mathrm{Ce}$ & $\mathrm{Ag}$ \\
\hline & $\begin{array}{l}\text { Saline } \\
\mathrm{TiO}_{2} \\
\mathrm{CeO}_{2} \\
\mathrm{Ag}\end{array}$ & $\begin{array}{c}0.611(0.256-1.431) \\
5.092(1.624-5.513)^{* * *}\end{array}$ & $\begin{array}{l}0.001(0.001-0.001) \\
0.004(0.001-0.007)^{* *}\end{array}$ & $\begin{array}{c}0.001(0.001-0.003) \\
5.484(2.872-7.136)^{* * *}\end{array}$ \\
\hline 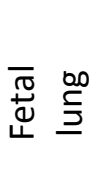 & $\begin{array}{l}\text { Saline } \\
\mathrm{TiO}_{2} \\
\mathrm{CeO}_{2} \\
\mathrm{Ag}\end{array}$ & $\begin{array}{l}2.298(2.013-3.082) \\
1.477(0.127-3.259)\end{array}$ & $0.001(0.001-0.001)$ & $0.054(0.036-0.066)^{* * *}$ \\
\hline
\end{tabular}

$\mathrm{n} \geq 4$ /group, Placenta and fetal lung were obtained at gestational day (GD) 17.5, Median values (interquartile range) are reported. Statistically significant differences between exposed and control groups are indicated as ${ }^{* *}: \mathrm{p}<0.01,{ }^{* *}: \mathrm{p}<0.001$. ICP-MS: Inductively Coupled Plasma Mass Spectrometry, Ti: Titanium, $\mathrm{TiO}_{2}$ : Titanium dioxide, $\mathrm{Ce}$ : Cerium, $\mathrm{CeO}_{2}$ : Cerium dioxide, Ag: Silver. 


\section{Figure legends}

\section{Figure 1: Pregnancy complications after NPs treatment}

Pregnant mice were treated by intratracheal instillation of $100 \mu \mathrm{g}$ of $\mathrm{TiO}_{2} \mathrm{NPs}, \mathrm{CeO}_{2}$ NPs, Ag NPs, or saline (control) once a week (gestational day (GD) 2.5, GD 9.5 and GD 16.5). (A) Maternal body weight during pregnancy was evaluated during exposure and two days prior to spontaneous delivery at GD 17.5 ( $\mathrm{n} \geq 15 /$ group). Ag NPs-exposed pregnant mice had a significantly lower weight than control pregnant mice. (B) Uterine weight ( $\mathrm{n} \geq 6$ /group). (C-D) Fetal resorption: pictures and quantification of fetal resorption rate ( $\mathrm{n} \geq 5$ /group), exposure to Ag NPs significantly increased the number of fetal resorptions (arrows). (E) Number of fetuses per litter ( $\mathrm{n} \geq 6$ /group). (F-G) Fetal weight ( $\geq 37 /$ group). (H) Placental efficiency ( $\mathrm{n} \geq 37 /$ group). Fetal weight and placental efficiency were significantly decreased following NPs exposure. Scale bar: $1 \mathrm{~cm}$. All data are expressed as the median and interquartile range. Statistically significant differences between exposed and control groups are indicated as $* * \mathrm{p}<0.01$ and $* * * \mathrm{p}<0.001$.

\section{Figure 2: Morphometric analysis of the lung of the offspring of NPs-treated mice}

Histological examination was performed on hematoxylin and eosin stained sections of pup lungs at (A) post-delivery day (PD) 14.5 and (B) PD 49.5, with evaluation of the mean linear intercept for estimation of alveolarization abnormalities. The mean linear intercept was significantly increased and the radial alveolar count was significantly decreased for both timepoints studied in the NPs-treated groups. Values are expressed as median and interquartile range. $n=10 /$ group. Statistically significant differences between NPs-exposed and control groups are indicated as $* \mathrm{p}<0.05, * * \mathrm{p}<0.01$ and $* * * \mathrm{p}<0.001$. 


\section{Figure 3: Silver element detection and localization in placenta and fetal lungs}

Hematoxylin and eosin (H\&E) staining and elemental XRF maps of sections of placenta and fetal lungs of the Ag NPs-exposed group (A). False colors used in correlation XRF maps represent $\mathrm{P}$ (green), $\mathrm{S}$ (blue) and Ag (red). Scale bar is $200 \mu \mathrm{m}$ (H\&E) and $50 \mu \mathrm{m}$ (XRF). Silver element was localized both in the chorionic plate of the placenta and in the lung. X-ray fluorescence spectra were obtained on areas marked by a white arrow (B). Positions of Ka fluorescence peaks of phosphorus (P), sulfur (S), potassium (K) and calcium (Ca) and $\mathrm{L}_{3,2}$ of silver (Ag) are represented together with the fit of the Ag contribution (red line). Silver spots were not present as "free" NPs, but were always co-localized with sulfur and phosphorus. XANES at the $\mathrm{Ag} \mathrm{L}_{3}$ edge of the reference compounds (Ag foil and pristine Ag NPs in saline solution) and representative silver spots located in the chorionic plate of the placenta (C). Comparison with the Ag L3 edge XANES spectra of referenced compounds (Ag foil and pristine Ag NPs in saline solution) revealed that most of the silver in this region remained in its metallic nano form. a.u: arbitrary unit.

\section{Figure 4: Expression of VEGF- $\alpha$ and MMP-9 in pup lungs}

VEGF- $\alpha$ mRNA expression (A) was significantly decreased in the $\mathrm{TiO}_{2} \mathrm{NPs}$ and $\mathrm{CeO}_{2}$ NPs groups in pup lungs at gestational day (GD) 17.5. MMP-9 mRNA expression (B) was significantly decreased for all NPs-exposed groups. VEGF- $\alpha$ protein expression (C) was significantly decreased in the $\mathrm{CeO}_{2} \mathrm{NPs}$ and $\mathrm{Ag}$ NPs groups in pup lungs at post-delivery day (PD) 14.5. MMP-9 protein expression (D) was similar to that observed in the control group. Values are expressed as median and interquartile range, $n=10 /$ group. Values are expressed as median and interquartile range, $n \geq 6 /$ group. Statistically significant differences between NPsexposed and control groups are indicated as $* \mathrm{p}<0.05$ and $* * \mathrm{p}<0.01$. 